\title{
ICT Definition Implication on ICT Career Choice and Exclusion among Women
}

\author{
Muchiri Michael Njoki \\ Department of Information Technology, Kibabii University; \\ Department of Information Technology, Dedan Kimathi University of Science and Technology, Kenya \\ E-mail: mnmuchiri@yahoo.com \\ Franklin Wabwoba \\ Department of Information Technology, Kibabii University, Kenya \\ E-mail: fwabwoba@kibabiiuniversity.ac.ke \\ Elyjoy Muthoni Micheni \\ Department of Management Science and Technology, The Technical University of Kenya, Kenya \\ E-mail: elyjoymicheni@gmail.com
}

\begin{abstract}
ICT is driving all areas of the economy and is likely to dictate the future for all genders. The narrow definition of ICT has greatly impacted on the female gender choosing ICT as a career of choice. There are few women in the ICT careers. The study sought to determine the nature of ICT career gender exclusion, status and trend of ICT job opportunities, source of ICT gender career exclusion and the contribution of the narrow definition to the exclusion. A mixed method of survey and desktop method was employed in this study. A structured questionnaire was used in this study in order to identify the factors that influence ICT career choice amongst Kenyan lady students. A purposive sample of Information Technology and Computer Science undergraduate university students (77 females, 56 males; age range 17 to 35 years) and 10 postgraduate students in Information Technology from two public universities participated in the study. The paper discusses the emerging unfilled ICT jobs. The study established that the narrow definition negatively influences ICT as a career of Choice among girls. Broadening ICT definition to include ICT related careers that have more social rather than technical aspect accordingly is likely to influence more women to join the field.
\end{abstract}

Index Terms - Career choice, ICT, ICT career gender exclusion, ICT jobs trends, Source of ICT gender career exclusion.

\section{INTRODUCTION}

"Career choice is a complex decision for students since it determines the kind of profession that they intend to pursue in life. As students try to make career choice while in secondary school, they face problem of matching their career choices with their abilities and school performance. In Kenya every year form four secondary school students make career choices before sitting for their final examination (Kenya Certificate of Secondary Education examinations) however, studies indicate that most students enter into careers that are totally different from the ones they chose while in secondary." [1]

Based on the above citation, it is apparent that career choice is quite challenging to many. The challenge is even more when it comes to ICT choices as many do not even understand or know the right definition or the different fields within it and yet the choices are entirely dependent on the individuals. The process of making a career choice by an individual is influenced by many factors ${ }^{[2]}$. The factors may vary from individual attributes, family back ground to cultural differences among others ${ }^{[3]}$. Studies have shown that some careers attract members of one gender more than the other. The scenario is very true for computer science which has seen the women and girls being seriously under represented ${ }^{[4]}$. Further studies have also shown that either gender could actually do as well in these kinds of careers ${ }^{[1]}$. ICT careers have been seen to be inequitable in terms of numbers in it especially when it comes to women. Generally women are underrepresented in ICT as they comprise basically only $30 \%$ of the ICT workforce worldwide ${ }^{[4]}$. What is even more worrying is the fact that few and few ladies seem to be taking on ICT careers and training at degree level.

Studies performed in a number of countries have majorly focused on the decline in female participation in disciplines such as engineering and computer sciences ${ }^{[6]}$. A growing concern in Kenya is in post-secondary institutions where there is low percentage of female students in Computing and information technology courses. The impact of this low enrollment ranges from a less valuable learning experience for the students who are enrolled to a lack of participation from females in the design of technology in our society. According to the UNESCO World Education Report of 2000 literacy rates in sub-Saharan Africa stand at $50.1 \%$ for women and $66.7 \%$ 
for men. More and more girls drop out of the education system between primary and secondary school and again at different secondary levels, making the disparities more glaring in higher education. According to this report women form only about $33 \%$ of the total enrolment in higher education.

Another observable fact noted worldwide is the disciplines or professions taken up by women at university level. Women are found mainly in education, humanities and social sciences rather than science, mathematics and technology ${ }^{[7]}$. There are a far smaller number of women in the computing and IT fields than men today. After research, the Association for Computing Machinery ${ }^{[8]}$ concluded that in general women stop their training in computer science earlier than men, thus accounting for the difference in proportion, especially at higher professional levels. While women receive about a third of the undergraduate computer science degrees, much fewer women receive master's degrees, and fewer still stay on to get their $\mathrm{PhDs}{ }^{[9]}$. This means that there are far more male computer science professors than female ones, which perpetuates the male-dominated atmosphere of computer science ${ }^{[10]}$.

The gender gap in ICT industry has been studied deeply and widely. Most of these researches indicate that over decades the industry is as one that favours males more than female in many fronts ${ }^{[5]}$. Gender inequality apparently has emerged on the use of ICT as a life enhancing tool, level of ICT awareness and representation in the industry ${ }^{[2] ~[11]}$. While some studies have shown the male gender as having more positive attitudes than female [12] [1], others have shown no difference in attitude between the genders ${ }^{[13]}$. The trends in the developed world indicate that some of these gaps somehow get reduced with time ${ }^{[5]}$. This may however be as a result of the affirmative action employed especially in the policy making within developed nations.

One way of addressing the gender gap in the ICT industry has been increasing the representation and participation of women in ICT ${ }^{[14]}$. Having more women take on ICT careers remains a great challenge in Kenya yet it is the step in the right direction. It our believe that the starting point towards achieving this would be at the school level as it is where the process of career choice starts, mainly in high school ${ }^{[1]}$. This is the time one starts thinking of what he/she would want to do in life. Studies have shown that most girls at this age shy away from ICT related courses/career ${ }^{[14]}$ fearing that ICT is a "man's" field ${ }^{[3]}$. This has in turn led to a skewed representation in favour of male in the industry. One is left wondering whether the narrow definition of IT may be contributing greatly to low participation of women in ICT industry.

This paper had the following objectives:-

(i) Determine the nature of enrollment by ladies into the Bachelor of Business Information Technology, Bachelor of Science (Information Technology) and Bachelor of Science (Information Technology) related undergraduate degree and the Master of Science (Information Technology) and Doctor of
Philosophy
(Information
Technology)

programmes

(ii) Investigate the status of ICT job opportunities trends

(iii) Determine the sources of the ICT career gender exclusion

(iv) Analysis how ICTs narrow definition affects ladies choice of ICT careers

This paper is organised in the following order: section 2.0 reviews literature in this area, section 3.0 provides the methodology, the findings of the study and their corresponding discussion is in section 4.0 while suggestions for the way forward come in section 5.0. The last section 6.0 gives the conclusion of the paper.

\section{ICT DEFINITION SCOPE AND THE GENDER GAP}

To define ICT to mean Computer science and engineering is a narrow perspective of looking at ICT. Such narrow definition has had major implications on the design and outcome of ICT research especially in gender ${ }^{[15]}$. Most research simply focus on the number of women in computer science and engineering field as a measure of their representation and participation in the ICT field. Obviously, these fields have a skewed bias that has favoured men and definitely has shown ICT as a masculine field ${ }^{[16]}$. As a result, girls are less likely to choose ICT as a career than their boys counterparts. Even when a girl may have had an interest in computing in her early years, the interest is likely to reduce as she grows older. It is not surprising that there are research findings that shows that many girls shy away from succeeding in areas believed to belong to men [12] [1]. The narrow definition has seen computer engineers and engineers being targeted for additional funding and government support at the expense of these other professions within the Information Society in many organisations and governments.

A broader definition of ICT that goes beyond the techno bits of ICT is therefore part of the solution to gender exclusion in ICT. Definitions that would be inclusive of Information science which attract more women than men would help change the trend. These areas are hardly focused on in ICT discussions despite them being key areas in the information society. A broader definition will bring professional from this background on board in discussing policy and contributing to decision making. This will not only increase the chances for women to take positions of leadership but will also influence the young scholars' altitudes towards this ICT based careers. It further implies that professionals from this area will be eligible to register in Computer Science and ICT professional bodies. This will in turn give them chances to contribute in decision making and influencing policy formulation aside from enhancing women's likely hood to be in senior positions in these bodies.

In broadening the definition of ICT beyond Computer Science and engineering, it has been suggested that ICT 
profession could be divided into three categories based on Denning's categorization $(2013)^{[17]}$ : IT specific disciplines, IT intensive and IT supportive discipline as indicated in Table 1 below.

Table 1. Categories of ICT disciplines

\begin{tabular}{|c|c|c|}
\hline $\begin{array}{l}\text { ICT-Specific } \\
\text { disciplines }\end{array}$ & $\begin{array}{l}\text { ICT-Intensive } \\
\text { disciplines }\end{array}$ & $\begin{array}{c}\text { ICT- } \\
\text { Supportive } \\
\text { occupations }\end{array}$ \\
\hline $\begin{array}{l}\text { - Artificial } \\
\text { Intelligence } \\
\text { - Computer } \\
\text { Science } \\
\text { - Computer } \\
\text { Engineering } \\
\text { - Computational } \\
\text { Science } \\
\text { - Database } \\
\text { Engineering } \\
\text { - Computer } \\
\text { Graphics } \\
\text { - Human Computer } \\
\text { Interaction } \\
\text { - Network } \\
\text { Engineering } \\
\text { - Operating } \\
\text { Systems } \\
\text { - Performance } \\
\text { Engineering } \\
\text { - Robotics } \\
\text { - Scientific } \\
\text { Computing } \\
\text { - Software } \\
\text { Architecture } \\
\text { - Systems security }\end{array}$ & 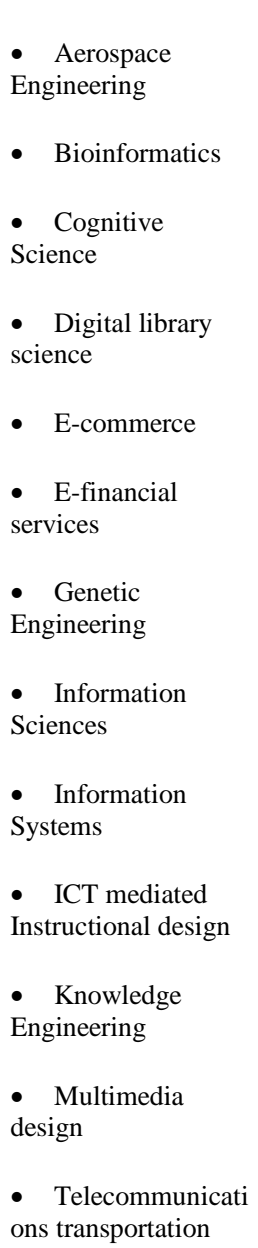 & $\begin{array}{l}\text { - Computer } \\
\text { Technician } \\
\text { - Help desk } \\
\text { technician } \\
\text { - Network } \\
\text { Technician } \\
\text { - Professional } \\
\text { ICT trainer } \\
\text { - Security } \\
\text { specialist } \\
\text { - Systems } \\
\text { Administrator } \\
\text { - Web } \\
\text { service } \\
\text { Administrator } \\
\text { - Web } \\
\text { Identity } \\
\text { designer } \\
\text { - Database } \\
\text { Administrator }\end{array}$ \\
\hline
\end{tabular}

\section{MethodOLOGY}

The mixed method research was used in this study. The integrated Literature survey research approach [18] was adopted in this study to identify relevant aspects with regard to career choices among students in Kenya, the narrow definition of ICT and Gender and ICT.

An exploratory survey was used in the study due to it its potential towards contribution to generation of new theories ${ }^{[19]}{ }^{[20]}$ especially in a topic like the one under this study that hardly has any studies on it. It was more suited for the study it is reported to be useful in less mature contexts, due its role in describing and establishing the basic understanding of a problem [21] [19]. Another reason for its use was its potential to focus on data reliability as result of obtaining it from a panel of experts ${ }^{[20]}{ }^{[19]}$ when used with focused group as was the case in this study. The exploratory survey was most appropriate as it allowed for increasing the flexibility of the research design in order to provide for opportunities to explore different aspects of the context at hand [19] [22]. In particular, it allowed for the creation of a broad and flexible research model might rely on a survey of relevant literature, a survey of existing practices, and expert consultations. Exploratory research is useful for the initial understanding of new phenomena, where the focus is broad and key issues have not, as yet, been identified ${ }^{[19]}$ is the case of ICT definition and careers choice.

Survey was undertaken on two public universities in Kenya to establish factors influencing ICT careers choice amongst ladies. Purposive sampling was undertaken to select a total of 77 females and 56 males whose age ranged 17 to 35 years based on the criteria that they were at least third or fourth year undergraduate student taking Information Technology or Computer Science programme from two public universities. The third or fourth year students had been exposed to programmes to be able to separate fears from reality in the discussion of the definition of ICT with career chose. In addition 10 (5 male and 5 female) postgraduate students were chosen randomly from amongst those pursuing Information Technology programme. Questionnaires, interviews and focused group discussions were the main tools used in the study. After a critical review combined with questionnaire responses of the selected literature addressing the study area had been conducted, interviews and focused discussion groups especially of graduate student were undertaken to identify the factors that influenced career choices, how the factors were affected by the narrow definition of ICT especially among girls and how this in turn influenced the participation of girls in the ICT arena.

Focused group was taken because they represent group judgments which are gathered over the integrated views and perceptions toward a concept ${ }^{[23][19]}$. Focused groups were used due to its usefulness in generating novel ideas. It allowed for participants to explain concepts [19], improve the credibility of the research as it eliminates biases which can occur in interviews ${ }^{[19]}$. It also was handy as it was considered to be cheap, less time consuming and quick and easy to be organized as compared to alternatives such as observation techniques [24].

\section{FINDINGS AND DISCUSSION}

Findings of the study are presented and discussed in this section. The findings are a result of documents analysis and focused group discussions with the sampled students.

\subsection{Enrollment per gender per course}

Findings with regard to students enrolled in three ICT based courses gender wise namely Bachelor of Business Information Technology -BBIT; Bachelor of Science (Computer Science) - BSc (Computer Science) and Bachelor of Science (Information Technology) - BSc 
(Information Technology) are presented in Table 2.

Table 2. ICT undergraduate students' registration per course per gender

\begin{tabular}{|c|c|c|c|c|c|}
\hline Programme & Year & Male & $\%$ & Female & $\%$ \\
\hline \multirow{2}{*}{ BBIT } & 1 & 45 & 77.59 & 13 & 22.41 \\
\hline & 2 & 25 & 75.76 & 8 & 24.24 \\
\hline \multicolumn{2}{|c|}{ Total BBIT } & 70 & 76.92 & 21 & 23.08 \\
\hline \multirow{4}{*}{$\begin{array}{c}\text { BSC } \\
\text { (Information } \\
\text { Technology) }\end{array}$} & 1 & 82 & 82.83 & 17 & 17.17 \\
\hline & 2 & 91 & 85.05 & 16 & 14.95 \\
\hline & 3 & 62 & 79.49 & 16 & 20.51 \\
\hline & 4 & 27 & 84.38 & 5 & 15.63 \\
\hline \multicolumn{2}{|c|}{$\begin{array}{c}\text { Total BSc } \\
\text { (Information } \\
\text { Technology) } \\
\end{array}$} & 262 & 82.91 & 54 & 17.09 \\
\hline \multirow{4}{*}{$\begin{array}{c}\text { BSc } \\
\text { (Computer } \\
\text { Science) }\end{array}$} & 1 & 105 & 94.59 & 6 & 5.41 \\
\hline & 2 & 115 & 87.12 & 17 & 12.88 \\
\hline & 3 & 81 & 91.01 & 8 & 8.99 \\
\hline & 4 & 93 & 93.00 & 7 & 7.00 \\
\hline \multicolumn{2}{|c|}{$\begin{array}{c}\text { Total BSc } \\
\text { (Computer Science) } \\
\end{array}$} & 394 & 91.20 & 38 & 8.80 \\
\hline Grand total & & 726 & 86.53 & 113 & 13.47 \\
\hline
\end{tabular}

Source: Dedan Kimathi University of Science and Technology and Kibabii University ICT schools

Generally, the enrolment of ladies in the three ICT based programmes is low across the board with none raising over $25 \%$ registration. The registration of ladies is lowest in Computer Science program $(8.8 \%)$ with an improved registration of $17.08 \%$ in Information Technology and best in Business Information Technology at $23.08 \%$. It is clear that the percentage registration improves as the field of specialty moves away from computer science that is closed associated in definition with mathematics and move towards Business Information Technology that is closely associated with the social sciences. From the interview findings with undergraduate students in the two universities revealed that the registration pattern was as a result of how closely the registration requirements being tied with performance at form level to mathematics and physics. In Computer Science where mathematics and physics are key requirements, the ladies enrolment was low. In Information Technology where enrolment is closely tied to mathematics but flexible on physics the enrolment is slightly better. There is a much improved enrolment in the Business Information Technology where physics is not a requirement and there is some flexibility of alternating mathematics requirement with a business subject in form four examination performances.

The requirement of mathematics and physics being requirements for admission to the ICT programmes combined with the field's definition being associated with mathematics is likely to be playing a role in exclusion of ladies from ICT careers as they perceive it to be a male gender career. There is hardly any evidence that students who lack on excelling in mathematics and physics at form four level do not perform well or deliver within the ICT career.

Findings with regard to students enrolled in Information Technology at Masters and Doctorate level per level gender wise are presented in Table 3.

Table 3. Masters and $\mathrm{PhD}$ IT student registration per year per gender

\begin{tabular}{|l|c|c|c|c|c|}
\hline Programme & Cohort & Male & $\%$ & Female & $\%$ \\
\hline \multirow{2}{*}{$\begin{array}{c}\text { MSc } \\
\text { (Information }\end{array}$} & 1 & 3 & 60.00 & 2 & 40.00 \\
\cline { 2 - 6 } Technology) & 2 & 6 & 75.00 & 2 & 25.00 \\
\cline { 2 - 6 } & 4 & 6 & 85.71 & 1 & 14.29 \\
\hline $\begin{array}{l}\text { Total MSc } \\
\text { (Information } \\
\text { Technology) }\end{array}$ & 1 & 12 & 100.00 & 0 & 0.00 \\
\hline $\begin{array}{l}\text { PhD } \\
\text { (Information } \\
\text { Technology) }\end{array}$ & 2 & 7 & 77.78 & 2 & 22.22 \\
\cline { 2 - 6 } & 3 & 3 & 60.00 & 2 & 40.00 \\
\hline $\begin{array}{l}\text { Total PhD } \\
\text { (Information } \\
\text { Technology) }\end{array}$ & $\mathbf{2 2}$ & $\mathbf{8 4 . 6 2}$ & $\mathbf{4}$ & $\mathbf{1 5 . 3 8}$ \\
\hline \multicolumn{1}{|c|}{ Grand total } & & 51 & 83.61 & 10 & 16.39 \\
\hline
\end{tabular}

Source: Dedan Kimathi University of Science and Technology and Kibabii University ICT schools

From table 3, it is apparent that the percentage of ladies representation in the Masters (17.14\%) and Doctorate $(15.38 \%)$ programmes has further dropped as compared to the undergraduate ones. The extreme low numbers of ladies at this level clearly implies reduced contribution by ladies on research and policy matters when it comes to ICT matters. As can be observed from Fig. 1 below there are many man by fur over the ladies representation

Trend of students' registration per Gender at given levels of study is provided in Figure 1 


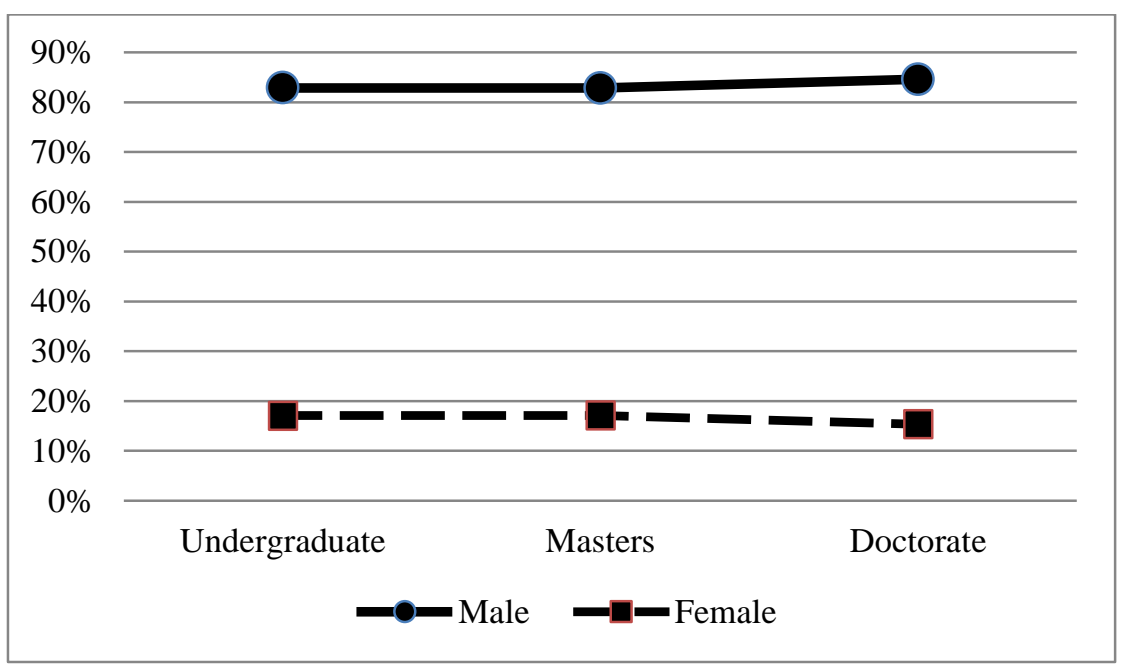

Fig.1. Trend of students' registration per Gender

Source: Dedan Kimathi University of Science and Technology and Kibabii University College ICT schools

It can also be noted from Figure 1 that while the representation of the male gender is rising as we move to the higher degree level training, the trends drops for the female gender.

\subsection{Gender gap in ICT}

From group discussion it was apparent there was a distinct gap between perception and use of ICTs and their applications between the different genders. The difference may be in the way they understand and use or prefer to use technology. These compliments well with the findings that men and women search for information differently on the Internet ${ }^{[25]}$. The difference observed is further reinforced by findings of Lee (2007) where it states that boys and girls at around 11 years old have been shown to have different interests in ICT. While more boys prefer the gaming aspect of the technology, the girls would rather get involved in online communities [13] an indication of how socialization pattern shape the difference in understanding and interpretation of issues (ICT included) between different genders ${ }^{[26]}$.

From the group discussion it also emerged that differences also exists in terms of the level of access, participation and representation. While some researchers have shown that women are indeed more productive, prolific, and effective than males in online environments [27] [13], it's unfortunate that on average men tend to have more access to the technology than women ${ }^{[5] ~[28] ~[29] . ~ T h e ~}$ difference in access has been attributed to various social and economic factors that generally place men at an advantage against women. This may include the difference in political and economic power among men and women, poverty, difference in education level among others [29] [30].

It was also noted from the focused groups that for most cases related to women, lack of access to ICTs obviously meant lack of use but the focused groups observed interestingly that there are cases where despite the access, however limited, there is minimal or no use at all. Some mobile users for instance only utilized only one or two services; calling / receiving calls and short message services. This is in spite of the mobile apps in their phones like the calculator or even internet services. Most of the affected users are mainly female. Lack of use may be attributed to different cultural expectations among males and female. As Young and Webb (2005) ${ }^{[31]}$ asserts men are more aggressive in presenting themselves. The boy child is expected to be more exploratory than girls. Probably this could explain why boys are more attracted to computer games than girls ${ }^{[13]}$ and why men more than women tend to discover more features from their gadgets other than those intended for primary use. Social norms where prime properties are "owned" by men would also force some women, though they may afford, not to invest in ICT gadgets that may seemingly put them at a higher level socially than the males in their lives, say a husband or a boss, for fear of being reprimanded. In fact the number of Women tends to reduce as one moves up the ladder of ICT careers training as can be seen in figure 2 .

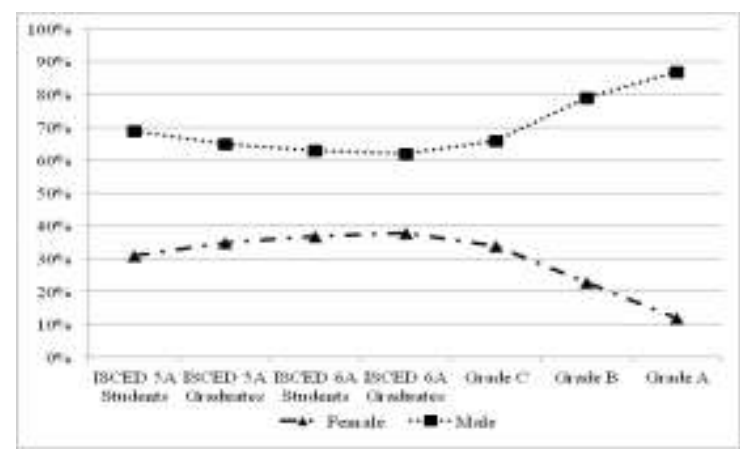

ISCED 5A: Tertiary level education suitable for employment in research

ISCED 6: Tertiary level education leading to advanced research qualification (PHD)

Grade $\mathrm{C}$ : First research grade for recent $\mathrm{PhD}$ graduate

Grade B: Mid level research grades

Grade A: Top level researchers

Fig.2. The proportion of men and women at different stages of a career in science and technology, 2006 
The representation gap is also evident in terms of the ratio of men to women in ICT careers. Not only do we have fewer women joining the ICT field, but also the retention rate for women in ICT is a problem as it emerged from the group discussions. Many women who studied ICT related courses are leaving the sector for other areas. There are even fewer women in the senior positions. According to some scholars, low performance and presentation of women in ICT has been attributed to; dominant male culture in ICT, Competitive work environment, difficulties in balancing work and family among others [31] [32]. What this researchers do not acknowledge however is that women are doing better in other equally competitive and demanding environments like nursing, marketing and education. These, therefore, most likely has got to do with perceptions that ICT is not stuff for women ${ }^{[28]}$.

The focused grouped also noted that the gap is wider among the developing countries and especially in rural areas a fact also supported by other studies [30] [33]. The gap is also evident in the societies where ICT is seen as men oriented career ${ }^{[14]}{ }^{[26]}$. Where such views have been overcome, like in some developed world nations, the gender gap in terms of participation and representation has been shown to reduce to insignificant levels. The performance of women has also been shown to rival that of men if not better ${ }^{[5]}$.

\subsection{The Unfulfilled ICT Jobs}

The digitization of almost every aspect of the modern society has produced a very high demand for ICT specialists ${ }^{[34]}$. Figure 3 shows a trend where the number of ICT specialists employed has been increasing in their thousands and their proportion among other jobs ${ }^{[35]}$.

Employment of ICT specialists in absolute terms and as a share of total employment (broad definition) 2004-2012

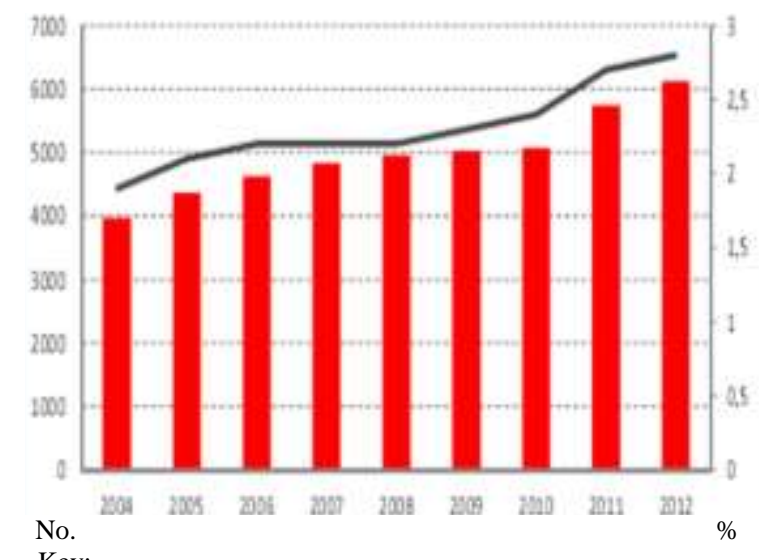

Key:

Red colour refers to ICT employment, 1000s

Black line refers to share in total, \%

Source: JRC (IPTS) "The evolution of EU ICT employment 20002012" Technical report (forthcoming)

Fig.3. Trends and filling of ICT job opportunities

Surprisingly most of ICT jobs vacancies are not filled.

There is a concern that there shall be more unfulfilled vacancies in this sector as demand is surpassing supply. Figure 4 shows a predicted growth of vacancies by 2020 in Europe only.

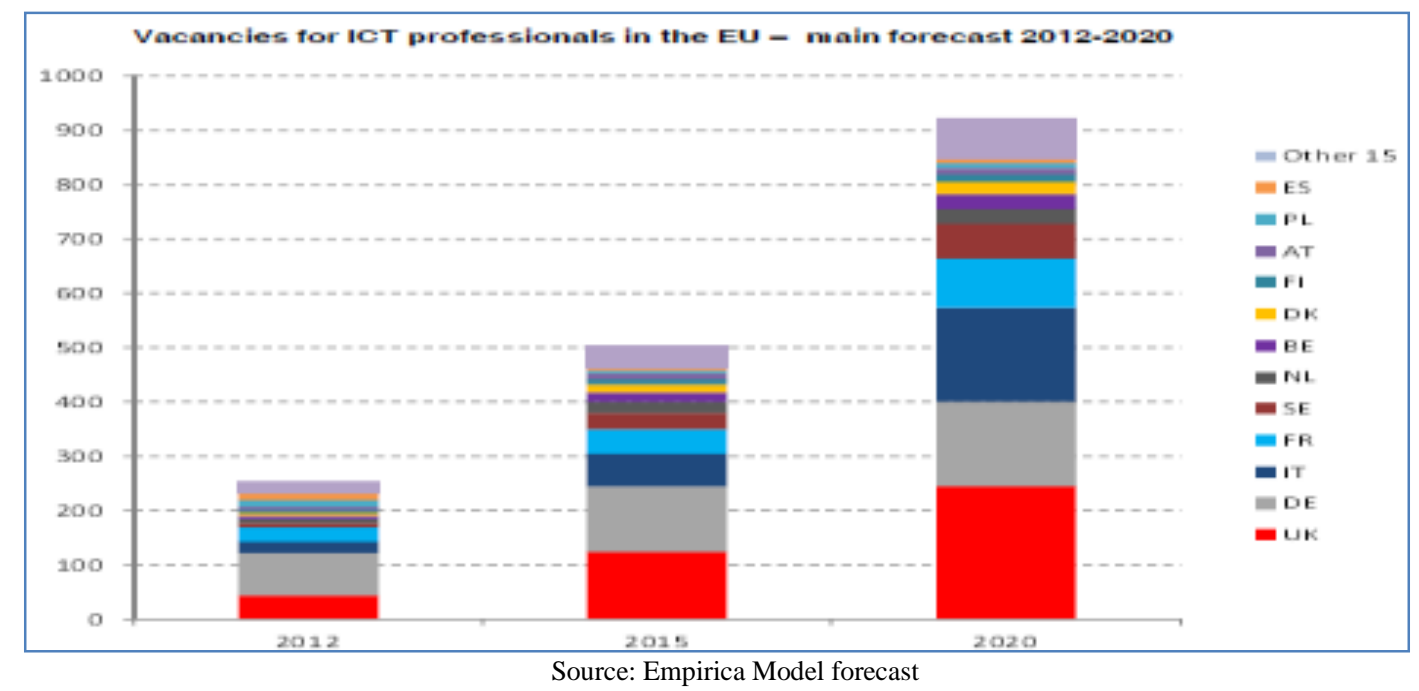

Fig.4. Vacancies for ICT professionals forecast in the European Union

The situation is made worse by the reducing number of students interested in computer related courses ${ }^{[36]}$. With the role ICT plays in shaping the economy [37], it's critical that the shortage of ICT specialists be addressed. The demand for ICT related jobs is increasing rapidly and it is estimated that by 2018 , half of the jobs will not be filled.

\subsection{Sources of girls shunning ICT Career choices}

Social economic status of a student plays a significant role in career choice among students ${ }^{[38]}$. Naong and Shumba (2012) ${ }^{[38]}$ asserts that most students especially from poor background will avoid careers that would take longer to train especially the girl child. The engineering courses take longer to complete than business related course in Kenya. Girls are likely to be more affected. Even in societies where early forced marriage for girls have been eradicated, social pressure and gender roles, in 
many cultures demand women to settle early in life. Constraining ICT to computer science and engineering would thus deter many students from picking ICT as their choice for career.

According to observations from the focused group discussion and Hewitt (2010), most peoples' career choice is influenced by careers that their parents favour, others follow the careers that their educational choices have opened for them. With fewer girls having a background in CS and Engineering their chances to make it in ICT are limited.

Some of the reasons Girls shy away from CS and engineering courses is the disciplines requirements for strong mathematics skills according to the findings of the focused group discussion, a fact that is complemented by findings of Kiplagat \& Rodrigues (2010) [39] in their study on science careers and ladies. It has also been shown in other research findings that generally girls perform poorer than boys in mathematics ${ }^{[40]}$, whether this should be the case or not is a debatable. Of course there are intervention measures being employed by various stake holders to improve the girls' performance in sciences and mathematics. As it is now any career therefore that requires mathematics as a prerequisite will attract fewer girls as opposed to boys and the scenario gets worse if physics is a requirement in addition. ICT courses like business Information Technology, Information systems, that have not emphasized so much in Mathematics have attracted more girls and their performance has been excellent it was observed from the focused group discussions.

The role model supportiveness and quality of relationship contributed to the career choice of students. Majority of the students selected same gender role models and they are not likely to choose careers where they see no role models. Interactions among peers also influence career choice ${ }^{[41]}$. Naong and Shumba (2012) asserts that family variables affect career choice. The parent's occupation influences the child's career choice. Sons are influenced more by fathers and girls by mothers. According to Castaño and Webster (2012) ${ }^{[16] ~ “ . . . W ~ W o m e n ~}$ still make up fewer than $20 \%$ of ICT professionals in most OECD countries..." and the situation is not getting any better and is worse in developing countries (Mohanan \& Shanta, 2008). As long women continue being under presented, girls will have fewer mothers to influence them in to choosing ICT related careers.

\subsection{How ICT definition affects women choice of ICT careers}

The shallow definition of ICT has caused, ICT professionals from CS and engineering being regarded more highly in the work places than those from alternative ICT fields. This has mainly affected women “...Even those who do enter ICT professions do not enjoy the same positions, pay and conditions as their male counterparts, and have far-from-smooth career trajectories over their lifetimes..." [16] This has resulted to some of these professionals feeling inferior to their counterparts from CS and engineering background despite some times performing better than them and this definitely puts off many girls who would otherwise join ICT career.

Boys and girls are inspired by different types of occupations. Watson et al (2010) ${ }^{[42]}$ found “...boys aspiring more to investigative and girls more to social type occupations..." This makes boys to be more inclined towards Sciences and Engineering course than girls. Constraining ICT to computer science and engineering creates the impression that; one has to have a background in these fields to succeed in ICT related careers ${ }^{[16]}$ There is, however, enough evidence to the contrary, where many professionals and especially women have entered the field through other gateways and excelled ${ }^{[43]}$, these alternative entry points to ICT are not accorded enough attention. Information and library science are ICT related careers with high degree of social dimension but highly ignored in the ICT debate.

The definition determines who is included and excluded in the discussions of policy processes ${ }^{[28]}$. The narrow definition of ICT has led to most of the ICT bodies and societies to be dominated and led by computer scientists and engineers. They thus control the decisions and policies that influence the ICT arena. This has led to fewer women rising to positions of leadership within the field ${ }^{[44]}$ we end up with no role models for our girls to look up to when making career choices

\section{SUGGESTIONS FOR THE WAY FORWARD}

From the discussion in the above sections, the narrow definition of ICT has been shown to have likely effects on the choice of ICT as a career among women. The narrow definition fails to account for a big number of women already in the ICT fields from alternative backgrounds other than Computer science and engineering. Perhaps we should redefine ICT to be more appealing to girls. ITU (2012) seems to be in agreement with this observation.

“...ITU Secretary-General, noted in launching the ITU Girls in ICT Portal, that "research consistently shows that girls tend to choose careers where they feel they can make a difference - healthcare, education, medicine. With this new portal, we're trying to show them that there's much more to ICTs than writing computer code ..." [37]

A broader definition would increases the visibility of other professions within ICT which are not necessarily CS or engineering. Such a definition will also see the government funding and support for research widen to include more areas in ICT that attract more women such as those in Information Technology studies and Computer studies education where teachers would be expected to acquire high skills in ICT in order to effectively integrate ICT in their teaching skills. This would go a long way in influencing the girl child's attitude on ICT considering that majority of primary school teachers are women ${ }^{[39]}$. Broadening the definition would go a long way to destroy the belief (and its consequent effects) that information technology is a 
masculine career.

There is need for a clearly planned undertaking to improve the enrolment of ladies into the ICT careers otherwise they risk being excluded over a period of time yet ICT is revolutionalising every sector on the globe. Role models from the same gender play a critical role in influencing the career choice among students. Broadening the definition of ICT would only not increase the number of women participating in the ICT arena but also make them more visible for the young girls to see and emulate. The broader definition would also see to the increase of the chances for women to be involved in making decisions and policy discussions. Policies that have critical gender considerations are likely to be developed in a broadened definition of ICT.

It was the view of UNESCO (2013) ${ }^{[4]}$ that gender issues must be fully integrated into technology analysis. Policy development and application design has to been done for both men and women to benefit equally from ICT and related technology ${ }^{[5]}$.The difference in how men and women are affected by ICT portrays itself in different ways. Effort needs to be made to avail ICTs and their apps to all gender at all levels of the social strata with deliberate effort to create awareness being created especially amongst ladies to motivate them to use them. There is need to understand why ladies why ladies tend not to explore the apps. In case the interfaces could be contributing then it would be worthwhile to tailor them towards their liking.

The ICT skill gap intervention measures so far have mainly target $\mathrm{CS}$ and Engineering professions. A broadened definition of ICT would expand the areas of research funded and supported by government and other agencies in reducing the skill gaps. This will include Information Technology, Information Systems, Information Science, Knowledge management and mass media among other ICT based careers that attract women more than men. Involvement of women from these backgrounds in ICT policy discussions will make the areas more visible to the young scholars.

Among the strategies that may be used to address ICT workforce shortage would be having girls develop interest in ICT. The exclusion or marginalization (or lack of it) of women in ICT is a clear illustration of how ICT directly impacts on the social economic development of the country ${ }^{[37]}$. According to Craig (2007) marginalizing part of the society will limit the range of skill sets, experiences and perspectives that would have otherwise enriched the sector ${ }^{[45]}$.

\section{CONCLUSION}

This paper looked at how career choices among women are influenced by the narrow definition of ICT. It acknowledges the under representation of women in the enrolment and engagement ICT field. It also discussed the growing unfulfilled gap of ICT jobs that women would help fill if availed with opportunities to join the field. The paper also discussed the factors affecting career choices and how these factors blended with the narrow definition to influence career choices among girls and especially in ICT. Finally the paper outlined the need to broaden the ICT definition, gave suggestions on the way forward and what further research to be considered in order to gain better understanding into the subject matter of lower numbers of women in ICT careers.

\section{ACKNOWLEDGMENT}

We appreciate the Study's financial sponsorship by the National Council of Science Technology and Innovation (Kenya).

\section{REFERENCES}

[1] Edwards and Quinter "Factors Influencing Students Career Choices among Secondary School students in Kisumu Municipality, Kenya" Journal of Emerging Trends in Educational Research and Policy Studies (JETERAPS), 2011, 2 (2): 81-87. Scholarlink Research Institute Journals, (ISSN: 2141-6990) jeteraps.scholarlinkresearch.org

[2] Ferry N.M "Factors Influencing Career Choices of Adolescents and Young Adults in Rural Pennsylvania" Extension Journal, 2006, 44( 3), Inc. ISSN 1077-5315

[3] Clayton, K "Engaging our future ICT professionals: What is the missing piece of the puzzle?" In Proceedings of Women, Work and IT, Contemporary Perspectives on the Reproduction of Gender Inequality in Employment. 2005, (Eds: Whitehouse, G. and Diamond, C.), School of Political Science and International Studies, University of Queensland.

[4] UN women "Girls in STEM and ICT Careers: The path toward gender Equality" UNESCO report, 2013

[5] Anyira, I. E. "Gender implication in awareness and use of search engines by private university lecturers in southsouth, Nigeria." Library Philosophy and Practice (ejournal), 2013, 1039. http://digitalcommons.unl.edu/libphilprac/1039

[6] Cukier W., Shortt D., \& Devine I. "Gender and Information Technology: Implications of Definitions", Journal of Information systems Education, 2011,13(1)

[7] Yen, J. W., Quinn, K., Lange S. E., Riskin E. A., Denton, D. D. "Advance Mentoring Program for Women Faculty in SEM at the University of Washington", ASEE Annual Conference Proceedings, Portland, OR./ ,2005

[8] ACM "Association for Computing Machinery Computing Surveys (CSUR)", 2005, 37:1 http://www.acm.org/

[9] Schrader, C., Hampikian, J., and Moll, A "What Women Want: Female- Friendly Faculty Recruitment", ASEE Annual Conference Proceedings, Chicago, IL, 2000, Paper 2006-2371.

[10] Connor H, Hillage J, Millar, J and Willison R "An Assessment of skill needs in information and communication technology", Institute for Employment Studies, 2001, draft report downloadable from www.skillsbase.dfee.gov.uk/Downloads/ICTreport.pdf

[11] Huyer, S., \& Sikoska T. "Overcoming the gender digital divide: Understanding ICTs and their potential for the empowerment of women" Instraw research paper series, 2003 no 1 Retrieved November 27, 2010, http://www.unesco.org/new/fileadmin/MULTIMEDIA/H Q/SHS/pdf/Overcoming-Gender-Digital-Divide.pdf

[12] Bandura A, Barbaranelli C, Caprara GV, Pastorelli C "Self-efficacy beliefs as shapers of children's aspirations 
and career trajectories" Child Development, 2001, 72: $187-206$.

[13] Lee, E. "Effects of gendered language on gender stereotyping in computer-mediated communication: The moderating role of depersonalization and gender-role orientation" Human Communication Research, 2007, 33: 515-535.

[14] Craig, A., Fisher, J., \& Lang, C. "ICT and girls: The need for a large scale intervention programme" In Proceedings of the 18th Australasian Conference on Information Systems, 2007, (pp. 761 - 769). Toowoomba, Qld, Australia, 5-7 December.

[15] Debra Howcroft \& Eileen M. Trauth, "The implications of a critical agenda in gender and IS research" Info Systems J, 2008, 18:185-202

[16] Castaño and Webster, "Understanding Women's Presence in ICT: the Life Course Perspective" International Journal of Gender, Science and Technology, 2012, 3(2) http://genderandset.open.ac.uk. In association with the Internet Interdisciplinary Institute, Open University of Catalonia

[17] Denning, P. "The Profession of IT: Who Are We?" Communications of the ACM, 2001,44(2): 15-18.

[18] Mbuguah. S and Karume S, "Trends in Electronic Money Transfer in Kenya" Journal of Emerging Trends in Computing and Information Sciences, 2013, 4(1)

[19] Alotaibi M. B "Mobile computing trends in Saudi Arabia: An exploratory study" I. J. Information Technology and Computer Science, 2015, 7(7): 19-27

[20] Armstrong J. S. "How tp avoid exploratory research" Journal of Advertising Research, 1970, 10:27-30

[21] Cheon M. J., Groven V. and Sabherwel "The evolution of empirical research in IS: a study in IS maturity" Information \& Management, 1993, 24:107-109

[22] Kothari C. R. "Research methodology: Methods and techniques" New age International, 2004

[23] Kitzinger J. "Qualitative research. Introducing focus groups" BMJ: British Medical Journal, 1995, 311:299

[24] Steward D. W. "Focus groups: Theory and Practice", Sage, 2007, 20

[25] Hotchkiss, G "Human hardware: men and women" Retrieved June 25, 2012 from www.searchengineland.com/human-hardware http://boingboing.net/2007/04/15/female-Internetuser.html http://scholarsarchive.jwu.edu/dissertations/AAI3177197

[26] Colley, A. "Gender differences in adolescents' perceptions of the best and worst aspects of computing at school" Computers in Human Behavior, 2003, 19:673-682.

[27] Caspi, A., Chajut, E., \& Saporta, K. "Participation in class and in online discussion: Gender differences" Computers \& Education, 2006, 50:718-724.

[28] Cukier, W. and Devine I. "Information Technology and Women's Participation: A Critical Perspective on IT Paradigms," Administrative Sciences Association of Canada Annual Conference (ASAC), London, Ontario, May 2001.

[29] Sumanjeet, "Social Implications of Electronic Commerce" Journal of Social Sciences, 2009, 21(2): 91-97

[30] Bimber, B. "Measuring the gender gap on the Internet" Social Science Quarterly, 2000, 81(3): 868-876.

[31] Young and Webb "Perhaps It's Time for a Fresh Approach to ICT Gender Research?” Journal of Research and Practice in Information Technology, 2005, 37(2) Australian Computer Society Inc

[32] Cuny, J. and Aspray, W. "Recruitment and Retention of Women Students in Computer Science and Engineering:
Results of a Workshop Organized by the Computing Research Association", San Francisco: Computing Research Association. (21-22 June 2000)

[33] Elijah, O.A and Ogunlade, I. "Analysis of the uses of information and communication technology for gender empowerment and sustainable poverty alleviation in Nigeria" International Journal of Education and Development using Information and Communication Technology (IJEDICT), 2006, 2(3): 45-69.

[34] World Economic Forum, "The Global Information Technology Report 2013" Growth and Jobs in a Hyperconnected World, 2013.

[35] European Commission "More women in senior positions; Key to economic stability and growth" Publications Office of the European Union, 2010. ISBN 978-92-7914415-8, doi: $10.2767 / 92882$

[36] Alexander P M, Holmner M, Lotriet H H, Matthee M C, Pieterse H V, Naidoo S, Twinomurinzi H and Jordaan D "Factors affecting career choice: Comparison between students from computer and other disciplines" 2010

[37] International Telecommunication Union, 2012

[38] Shumba A \& Naong M, "Factors Influencing Students' Career Choice and Aspirations in South Africa" Journal of Social Sciences, 2012, 33(2):169-178.

[39] Kiptalam, G.K and Rodrigues, A.J. "Internet Utilization: A Case of Connected Rural and Urban Secondary Schools in Kenya" International Journal of Computing and ICT $\begin{array}{llll}\text { Research, } & 2010, & 4(1): 49 & -\end{array} 6$ http://www.ijcir.org/volume4-number1/article6.pdf

[40] Wasike y, 2009

[41] Pummel, B., Harwood, C. and Lavallee, D. "Jumping to the next level: A qualitative examination of within career transition in adolescent's event riders" Psychology of Sport and exercise, 2008, 9(4): 427-447.

[42] Watson M, McMahon M, Foxcroft C, Els C. "Occupational aspirations of low socio-economic Black South African children", 2010

[43] Valenduc G. "Not a Job for Life? Women's Progression, Conversion and Dropout in ICT Professions" International Journal of Gender, Science and Technology, 2011, 3(2): 483-500

[44] Perrone K.M., Sedlacek E.W. \& Alexander M.C. "Gender and ethnic differences in career goal attainment" Career Development Quarterly, 2001, 50 (2):168-178

[45] O'Neill K \& Shortt D "ICT and Women. Information Technology Association of Canada" Journal of Career Development, 2009, 37(4): 717-734. Doi:10.1177/08948 45309359351.

\section{Authors' Profiles}

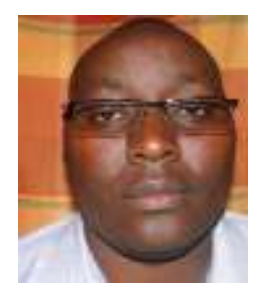

Muchiri M. Njoki was born at Kiambu in Kenya on $13^{\text {th }}$ February 1977 . He is a PhD in Information Technology (student) at Kibabii University in Bungoma County (Kenya). He is an MSc (Computer Based Information Systems) from University of Sunderland (UK) and a BEd (Science) from Kenyatta University, Nairobi (Kenya). He is an Assistant Lecturer in the Department of Information Technology at Dedan Kimathi University of Technology (DeKUT), Nyeri (Kenya). He has also held the following positions Acting Director E-Learning Center DeKUT, Mathematics and Physics teacher. Mr. Muchiri's research interests include, digital inclusion, ICT for Development, and 
Education and ICT. Mr. Muchiri is a member of the Internet Society Kenyan Chapter.

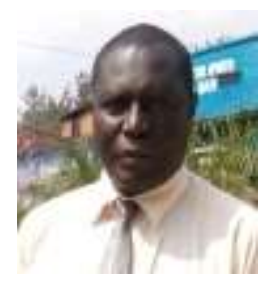

Dr. Franklin Wabwoba is a Senior lecturer in Information Technology and Dean of the School of Computing and Informatics at Kibabii University (Kenya). He holds a PhD (Information Technology) from Masinde Muliro University of Science and Technology, Master of Science (Computer Applications) from Kenyatta University; Endorsement (Educational Management) from University of South Africa and Bachelor of Education (science: Mathematics and Computer Science) from Egerton University. He has taught Computer Science and Information Technology courses for many years. He has ICT industrial experience having worked with Mumias Sugar Company. He has presented several papers in scientific conferences and has many publications in referred journals as well as university level computing books. He has a strong research interest in green ICT, the impact of ICT applications on the community and integration of ICT into education. He is a professional member of the Association for Computing Machinery (ACM).

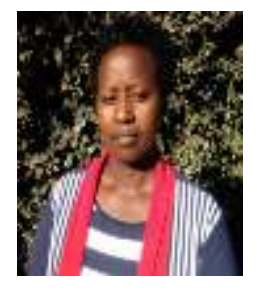

Dr. Elyjoy M. Micheni is a lecturer in Information Systems and the Chairperson, Department of Management Science and Technology at The Technical University of Kenya. She holds a PhD (Information Technology) from Masinde Muliro University of Science and Technology, Master of Science (Computer Based Information Systems) from Sunderland University, (UK); Bachelor of Education from Kenyatta University; Post Graduate Diploma in Project Management from Kenya Institute of Management. She has taught Management Information System courses for many years at University level. She has presented papers in scientific conferences and has many publications in referred journals. She has also co-authored a book for Middle level colleges entitled: "Computerized Document Processing". Her career objective is to tap computer based knowledge as a tool to advance business activities, promote research in ICT and enhance quality service.

How to cite this paper: Muchiri Michael Njoki, Franklin Wabwoba, Elyjoy Muthoni Micheni,"ICT Definition Implication on ICT Career Choice and Exclusion among Women", International Journal of Information Technology and Computer Science(IJITCS), Vol.8, No.5, pp.62-71, 2016. DOI: 10.5815/ijitcs.2016.05.07 